\title{
TUTUPAN KARANG LUNAK DI PERAIRAN DESA PANDANGA KABUPATEN PULAU MOROTAI
}

\author{
Kismanto Koroy, Nurafni, Nurman Husain \\ Program Studi IImu Kelautan, Fakultas Perikanan dan IImu Kelautan, \\ Universitas Pasifik Morotai, Maluku Utara, Indonesia \\ E-mail: kismantokoroy@gmail.com
}

Received February 2020, Accepted April 2020

\begin{abstract}
ABSTRAK
Terumbu karang memiliki keunikan diantara asosiasi atau komunitas lautan yang seluruhnya dibentuk oleh kegiatan biologis. Umumnya terdapat karang keras (hard coral) dan karang lunak (soft coral). Karang lunak (Octocorallia, Alcyonacea) merupakan hewan anggota Colenterata yang hidup di perairan dangkal tropis dan subtropis. Tujuan penelitian ini adalah untuk mengidentifikasi karang lunak, dan menganalisis persen tutupan terumbu karang pada daerah rataan dan daerah tubir di perairan Desa Pandanga, Kabupaten Pulau Morotai. Penelitian ini dilakukan pada bulan November - Desember 2019. Pengambilan data karang menggunakan metode LIT, dengan menetapkan 4 (empat) stasiun pengamatan masing-masing stasiun yang dibagi menjadi 2 (dua) daerah yaitu pada daerah tubir dan rataan. Setiap lifeform karang yang dilewati transek di dokumentasi dalam bentuk gambar yang selanjutnya akan diidentifikasi dan menghitung persentase tutupan karang lunak. Hasil penelitian menunjukan karang lunak yang ditemukan sebanyak 7 (tujuh) genus yaitu Sinularia, Isis, Cladiella, Lobophytum, Sarcophyton, Klyxum, dan Rumphella. Hasil analisis persen tutupan tertinggi untuk semua stasiun terdapat pada genus Sinularia $(20,6 \%)$ di daerah tubir, sedangkan pada daerah rataan dengan persentase tertinggi terdapat pada genus Lobophytum (8,0\%).
\end{abstract}

Kata kunci : Persen Tutupan, Karang Lunak, Morotai

\section{ABSTRACT}

SOFT CORAL COVERAGE IN PANDANGA VILLAGE WATERS, MOROTAI ISLAND REGENCY. Coral reefs are unique among oceanic associations or communities that are entirely formed by biological activities. Generally there are hard corals and soft corals. Soft corals Octocorallia, Alcyonacea) are members of the Colenterata that live in tropical and subtropical shallow waters. The aim of this study was to identify soft corals and analyze the percent cover of coral reefs in the flat areas and slope areas in the waters of Pandanga Village, Morotai Island Regency. This research was conducted in November-December 2019. 
The collection of coral data using the LIT method, by determine 4 (four) observation stations of each station which are divided into 2 (two) regions that in reef flat areas and reef slope areas. Each coral lifeform crossed by a transect is in the form of an image which will then be identified and calculate the percentage of soft coral cover. The results showed that there were 7 (seven) genera of soft corals Sinularia, Isis, Cladiella, Lobophytum, Sarcophyton, Klyxum, and Rumphella. The results of the highest percent cover analysis for all stations are in the genus Sinularia (20.6\%) in the flat area, in reef flat areas the highest percentage in the genus Lobophytum (8.0\%).

Keywords : Percent Cover, Soft Coral, Morotai

\section{PENDAHULUAN}

Terumbu karang memiliki keunikan diantara asosiasi atau komunitas lautan yang seluruhnya dibentuk olehaktivitas biologis. Terumbu adalah endapan-endapan masif penting dari kalsium karbonat yang terutama dihasilkan oleh karang. Umumnya terdapat karang keras (hard coral) dan karang lunak (soft coral). Karang lunak (Octocorallia atau Alcyonacea) merupakan hewan anggota Coelenterata yang hidup di perairan dangkal tropis dan subtropis (Manuputty, 2016). Karang lunak merupakan bagian dari ekosistem terumbu karang yang tersebar di perairan dangkal yang mempunyai peranan biologis bagi kelangsungan hidup biota perairan lain yang berasosiasi dengan ekosistem terumbu karang. Selain memiliki fungsi biologis, karang lunak juga memiliki nilai ekonomis untuk kegiatan wisata dan biasa digunakan sebagai karang hias karena memiliki corak warna yang menarik.

Berdasarkan sifat-sifat Paleogeologi, Perairan Pulau Morotai termasuk dalam klasifikasi terumbu karang Indo-Pasifik yang mencakup Obi, Bacan, Halmahera, dan Morotai (Kordi, 2010). Pulau Morotai merupakan daerah tujuan wisata yang ditetapkan pemerintah sebagai 10 kawasan destinasi wisata Indonesia. Sebagai daerah tujuan wisata bahari, salah satu kegiatan yang dikembangkan adalah wisata selam dengan mengandalkan ekosistem terumbu karang. Ekosistem terumbu karang diketahui memiliki daya tarik eksotik karena memiliki banyak macam jenis karang termasuk di dalamnya adalah karang lunak.

Sebaran karang lunak secara spesifik di Perairan Desa Pandanga dan umumnya di Kabupaten Pulau Morotai masih sangat terbatas. Keterbatasan informasi tentang karang lunak merupakan masalah yang penting untuk diperhatikan, karena diketahui karang lunak memiliki fungsi penting baik secara ekologis maupun ekonomis. Selain itu, pemahaman masyarakat secara umum tentang karang lunak masih sangat minim, karena keberadaannya pada ekosistem terumbu karang kebanyakan di dominasi oleh karang keras. Dominasi suatu jenis karang pada suatu habitat bergantung pada kondisi lingkungan atau habitat tempat karang itu hidup, penggolongan habitat secara geomorfologi seperti daerah rataan dan daerah tubir memiliki karakteristik yang berbeda dengan tingkat 
respon terhadap tekanan lingkungan yang berbeda pula. Berdasarkan uraian latar belakang di atas maka perlu dilakukan penelitian tentang Tutupan Karang Lunak (Soft coral) pada daerah rataan dan tubir di perairan Desa Pandanga Kabupaten Pulau Morotai.

\section{MATERI DAN METODE}

\section{Waktu dan Tempat}

Penelitian ini dilaksanakan pada bulan November - Desember 2019. Pengambilan data lapangan dimulai pada bulan November, dilanjutkan dengan identifikasi dan tabulasi data karang. Adapun tempat penelitian berlokasi di Perairan Desa Pandanga, Kecamatan Morotai Selatan, Kabupaten Pulau Morotai. Berikut gambar peta lokasi penelitian.

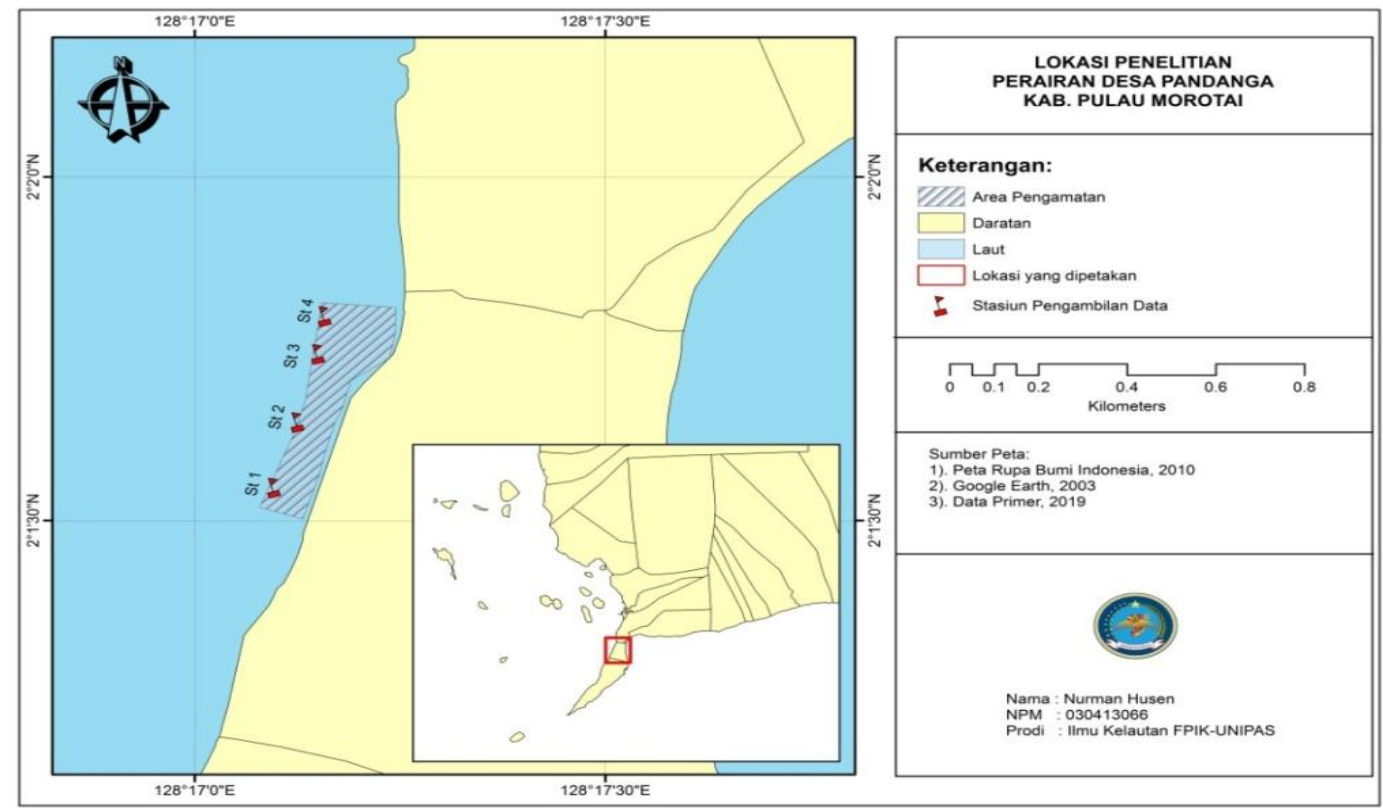

Gambar 1. Peta lokasi penelitian

\section{Alat dan Bahan}

Alat dan bahan yang digunakan dalam penelitian ini adalah Scuba, meteran roll, kamera bawah air, secchi disc, oxygen meter, hanna meter, hand refraktometer, current meter, buku identifikasi karang Suharsono (2008) dan Fabricius et al., (2001).

\section{Prosedur Pengambilan Data}

Pengambilan data dilakukan dengan petunjuk English et al., (1997), dimana ukuran transek sepanjang $50 \mathrm{~m}$ mengikuti arah garis pantai. Lokasi pengambilan data ditetapkan setelah melihat hasil yang diperoleh melalui observasi awal, dimana pada setiap lokasi ditentukan 2 (dua) titik 
pengambilan sampel untuk dijadikan lokasi peletakan transek dengan teknik Line Intercept Transect (LIT). Pengambilan data karang ditetapkan pada 4 (empat) stasiun pengamatan dengan masing-masing stasiun yang dibagi menjadi 2 (dua) daerah yaitu pada daerah tubir dan rataan. Menurut (Nababan et al., 2015) menjelaskan bahwa pengamatan dilakukan dengan cara mencatat jenis karang lunak yang ditemukan disepanjang garis transek pada daerah rataan dan daerah tubir. Setiap lifeform karang yang dilewati transek didokumentasi dalam bentuk gambar yang selanjutnya akan diidentifikasi dengan menggunakan buku identifikasi menurut Suharsono (2008) dan Fabricius (2001). Berikut sketsa pengambilan data karang (Gambar 2).

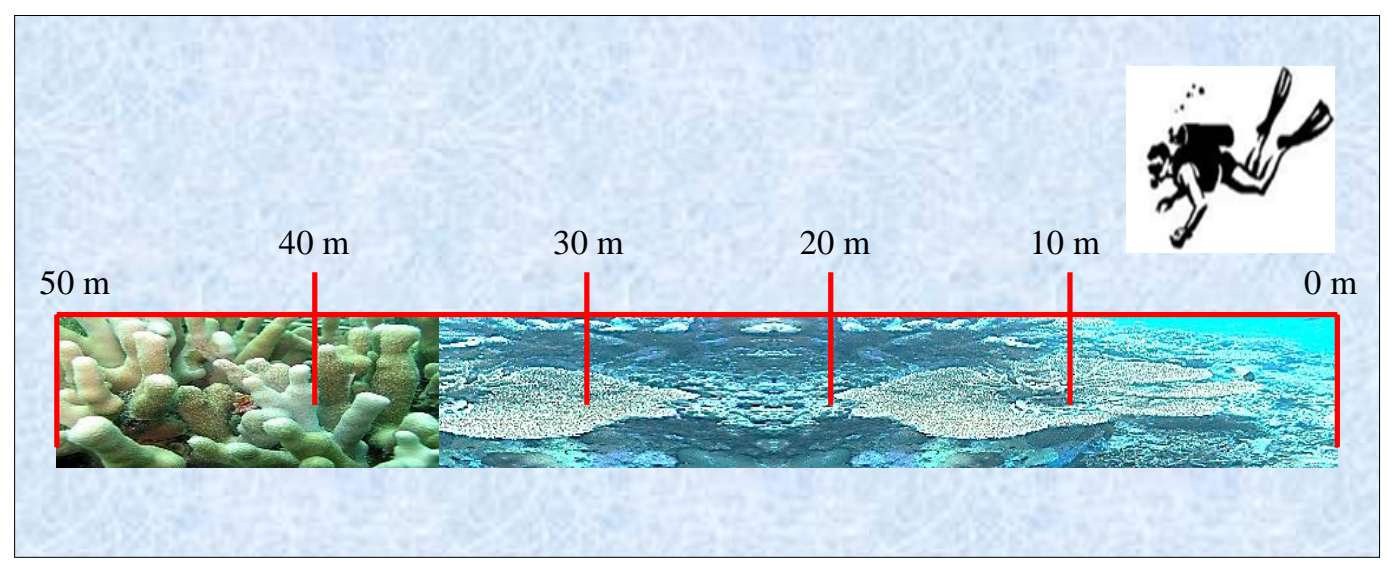

Gambar 2. Ilustrasi Line Intercept Transect (LIT)

\section{Analisis data}

\section{Persen Tutupan Karang Lunak}

Menurut English et al. (1997) bahwa perhitungan presentase tutupan karang (Percent of kategori Cover) bagi masing-masing kategori pertumbuhan karang hidupdengan cara membandingkan panjang total setiap kategori dengan panjang transek total menggunakan persamaan berikut.

$$
\text { Percent cover }=\frac{\text { Total Lenght of Category }}{\text { Total Of Transect }} \times 100 \%
$$

Kategori tutupan karang mengikuti Gomes dan Yap (1984) ditunjukkan dalam Tabel 1.

Tabel 1. Kategori persen tutupan karang

\begin{tabular}{ll}
\hline Tutupan (\%) & Kategori \\
\hline $0-24,9$ & Buruk \\
$25-49,9$ & Sedang \\
$50-74,9$ & Baik \\
$75-100$ & Sangat baik \\
\hline
\end{tabular}




\section{HASIL DAN PEMBAHASAN}

\section{Parameter Kualitas Perairan}

Parameter perairan sebagai faktor fisika memegang peranan penting dalam pertumbuhan karang. Pertumbuhan karang akan baik, apabila memiliki kondisi fisika perairan yang relatif baik pula dan sesuai standar baku mutu perairan untuk pertumbuhan karang. Berikut parameter perairan hasil pengukuran lapangan dapat dilihat dalam Tabel 2.

Tabel 2. Parameter fisika-kimia Perairan Desa Pandanga

\begin{tabular}{lllll}
\hline \multirow{2}{*}{ Parameter } & \multicolumn{4}{l}{ Lokasi Pengukuran } \\
\cline { 2 - 5 } & Stasiun 1 & Stasiun 2 & Stasiun 3 & Stasiun 4 \\
\hline Suhu ( $\left.{ }^{\circ} \mathrm{C}\right)$ & 29,1 & 29,3 & 29,6 & 29,1 \\
Salinitas (\%o) & 34 & 34 & 34 & 34 \\
pH & 7,2 & 7,4 & 7,3 & 7,3 \\
Kecerahan (m) & 7,5 & 7,5 & 7,5 & 7,5 \\
Kecepatan Arus (m/dt) & 0,10 & 0,08 & 0,07 & 0,07 \\
Kedalaman (m) & $3-5$ & $3-5$ & $3-5$ & $3-5$ \\
\hline
\end{tabular}

Tabel 2 menunjukan kondisi parameter perairan di lokasi penelitian, untuk sebaran suhu perairan dari stasiun I sampai IV memiliki nilai kisaran 29,1 - 29,6 ํ․ Menurut PERMEN-LH nomor 4 Tahun 2001, mengacu pada baku mutu perairan untuk suhu perairan laut berada pada kisaran 28 $-30^{\circ} \mathrm{C}$, masih tergolong baik untuk pertumbuhan karang. Perkembangan terumbu yang paling optimal terjadi di perairan yang rata-rata suhu tahunannya $23-25^{\circ} \mathrm{C}$, Namun, terumbu karang juga mentoleransi suhu hingga 36 - $40 \stackrel{\circ}{\circ}$ (Nybakken, 1988). Faktor lain yang membatasi perkembangan terumbu karang adalah salinitas. Salinitas yang normal untuk pertumbuhan karang adalah 32 - 35\%o (Nybakken, 1988). Hasil pengukuran menunjukan salinitas di lokasi pengambilan sampel memiliki salinitas $34 \%$ o. Kondisi perairan berkaitan dengan tingkat kecerahan air. Hasil pengukuran di lokasi pengamatan tergolong masih sangat baik. Hal ini dapat dilihat dari kecerahan perairan memiliki nilai rata-rata $7,5 \mathrm{~m}$ di semua stasiun yang berada pada kedalaman 5 meter.

\section{Karang Lunak yang Teridentifikasi}

Karang lunak yang ditemukan dilokasi penelitian dapat diklasifikasikan menjadi 3 (tiga) famili yaitu Alcyoniidae, Isisdidae, dan Gorginiidae yang termasuk dalam klas Anthozoa. Klasifikasi karang lunak menurut Fabricius, et al., (2001) membagi 7 (tujuh) genus kedalam 3 famili. Pengelompokan karang lunak dilakukan agar dapat mempermudah mengenali, membandingkan ciri setiap individu yang dimilikinya. Klasifikasi karang lunak berdasarkan kelas, famili dan genus dapat dilihat dalam Tabel 3. 
Tabel 3. Klasifikasi karang lunak (Kelas, Famili, dan Genus)

\begin{tabular}{llll}
\hline Kelas & Famili & Genus & Spesies \\
\hline & & Sinularia & Sinularia leptoclados (Ehrenbeg, \\
& & 1834) \\
& & Cladiella & Cladiella sp. \\
& Alcyoniidae & Klyxum & Klyxum sp. \\
Anthozoa & & Sarcophyton & Sarcopyton ehrenbergi (Von \\
& & Marenzellrr, 1986) \\
& & Lobophytum & Lobophytum sp. \\
& Isididae & Isis & Isis hippuris \\
& Gorginiidae & Rumphella & Rumphella sp. \\
\hline
\end{tabular}

Hasil pengamatan di lokasi penelitian ditemukan 7 (tujuh) genus dengan sebaran masing-masing di setiap stasiun pada daerah rataan dan daerah tubir. Karang lunak yang ditemukan diantaranya Sinularia, Isis, Cladiella, Lobophytum, Sarcophyton, Klyxum, dan Rumphella. Adapun sebaran karang lunak yang ditemukan di lokasi penelitian untuk semua stasiun pada daerah rataan dan daerah tubir dapat dilihat dalam Tabel 4.

Tabel 4. Karang lunak yang ditemukan

\begin{tabular}{|c|c|c|c|c|c|c|c|c|}
\hline \multirow[t]{2}{*}{ Genus } & \multicolumn{2}{|c|}{ Stasiun 1} & \multicolumn{2}{|c|}{ Stasiun 2} & \multicolumn{2}{|c|}{ Stasiun 3} & \multicolumn{2}{|c|}{ Stasiun 4} \\
\hline & $\begin{array}{l}\text { Rata- } \\
\text { an }\end{array}$ & Tubir & $\begin{array}{l}\text { Rata- } \\
\text { an }\end{array}$ & Tubir & $\begin{array}{l}\text { Rata- } \\
\text { an }\end{array}$ & Tubir & $\begin{array}{l}\text { Rata- } \\
\text { an }\end{array}$ & Tubir \\
\hline Sinularia & + & + & + & + & + & + & + & + \\
\hline Isis & + & + & + & + & - & - & + & - \\
\hline Cladiella & + & + & + & + & - & - & - & - \\
\hline $\begin{array}{l}\text { Lobophy- } \\
\text { tum }\end{array}$ & + & - & + & + & - & - & + & - \\
\hline $\begin{array}{l}\text { Sarcophy- } \\
\text { ton }\end{array}$ & - & + & - & + & - & - & + & + \\
\hline Klyxum & - & - & - & - & - & + & - & - \\
\hline Rumphella & - & - & - & + & - & + & - & - \\
\hline
\end{tabular}

Keterangan: ( + ) ditemukan; ( - ) tidak ditemukan

Sebaran karang lunak sebagaimana dalam Tabel 4 di atas memperlihatkan bahwa Sinularia. dapat di temukan disemua daerah rataan dan daerah tubir pada semua stasiun. Isis tidak ditemukan di stasiun 3 (daerah rataan dan tubir) dan juga pada stasiun 4 di daerah tubir. Cladiella hanya ditemukan di stasiun 1 dan 2, dan tidak ditemukan di stasiun 3 dan 4. Lobophytum kehadirannya dapat ditemukan di semua daerah (rataan dan tubir) untuk stasiun 2, dan tidak ditemukan di stasiun 3 baik di daerah rataan maupun daerah tubir, sedangkan pada stasiun 1 dan stasiun 4 hanya ditemukan di daerah rataan dan tidak ditemukan pada daerah tubir. Sarcophyton banyak ditemukan di daerah tubir (stasiun 1, 2, dan 4) dan hanya ditemukan pada 1 (satu) stasiun untuk daerah 
rataan yaitu di stasiun 4, sedangkan pada stasiun 3 tidak ditemukan. Klyxum termasuk yang paling sedikit, sebarannya hanya ditemukan pada daerah tubir di stasiun 3 dan tidak ditemukan stasiun 1, 2, dan 4 . Rumphella merupakan karang lunak yang hanya ditemukan di daerah tubir pada lokasi penelitian yaitu di stasiun 2 dan 3 . Berikut karang lunak yang diidentifikasi (Gambar 3).

\section{Tutupan Karang Lunak}

Analisis tutupan karang lunak pada stasiun I menunjukan karang lunak pada daerah tubir untuk genus Isis memiliki persentase paling tinggi yaitu $15,32 \%$ dan terendah pada Sarcophyton (0,48\%). Sedangkan tutupan karang lunak pada daerah rataan dengan persentase tertinggi terdapat pada Sinularia dan Cladiella $(5,46 \%)$ dan terendah terdapat pada genus Lobophytum $(0,74 \%)$.

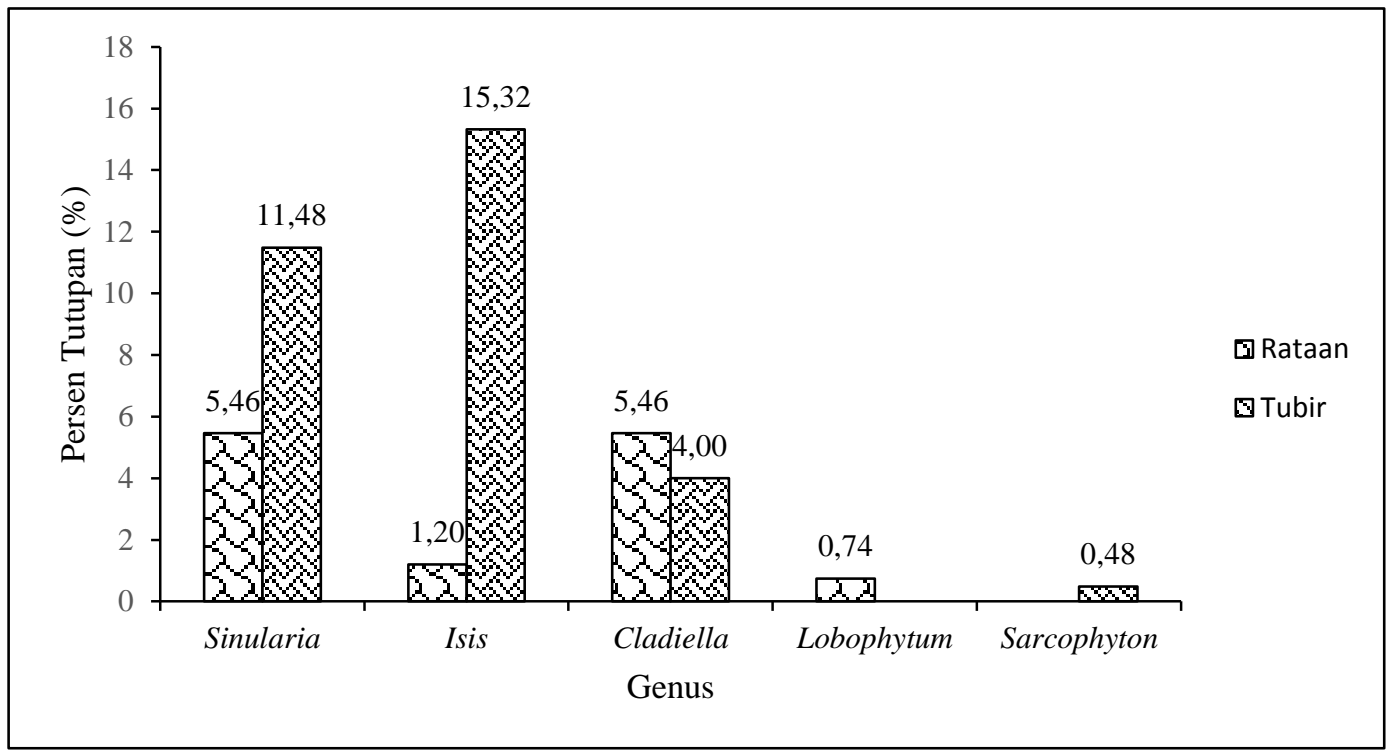

Gambar 3. Persentase Tutupan Karang Lunak di Stasiun I

Menurut Haris et al., (2010), karang lunak Isis banyak ditemukan pada zona reef slope dengan kondisi perairan memiliki arus yang lemah dan dapat hidup pada kedalaman paling rendah 3 meter. Selanjutnya menurut Fabricius dan Alderslade (2001) dalam Lubis et al., (2016) menyatakan bahwa umumnya Isis banyak ditemukan pada daerah dangkal yang aman dari aksi gelombang dan memiliki perairan yang jernih. Hal ini dapat sesuai dengan kondisi perairan di lokasi penelitian pada stasiun I pada daerah tubir masih tergolong memiliki gelombang dan arus yang masih lemah dengan kondisi perairan jernih.

Tutupan karang lunak pada stasiun II dengan persentase tertinggi terdapat pada genus Sinularia $(20,60 \%)$ yaitu di daerah tubir, sedangkan pada daerah rataan, genus Lobophytum memiliki tutupan paling tinggi dengan persentase $6,90 \%$. Persentase tutupan terendah untuk kedua 
daerah rataan dan tubir terdapat pada genus Cladiella $(0,66 \%)$ pada rataan dan $(1,16 \%)$ pada daerah tubir.

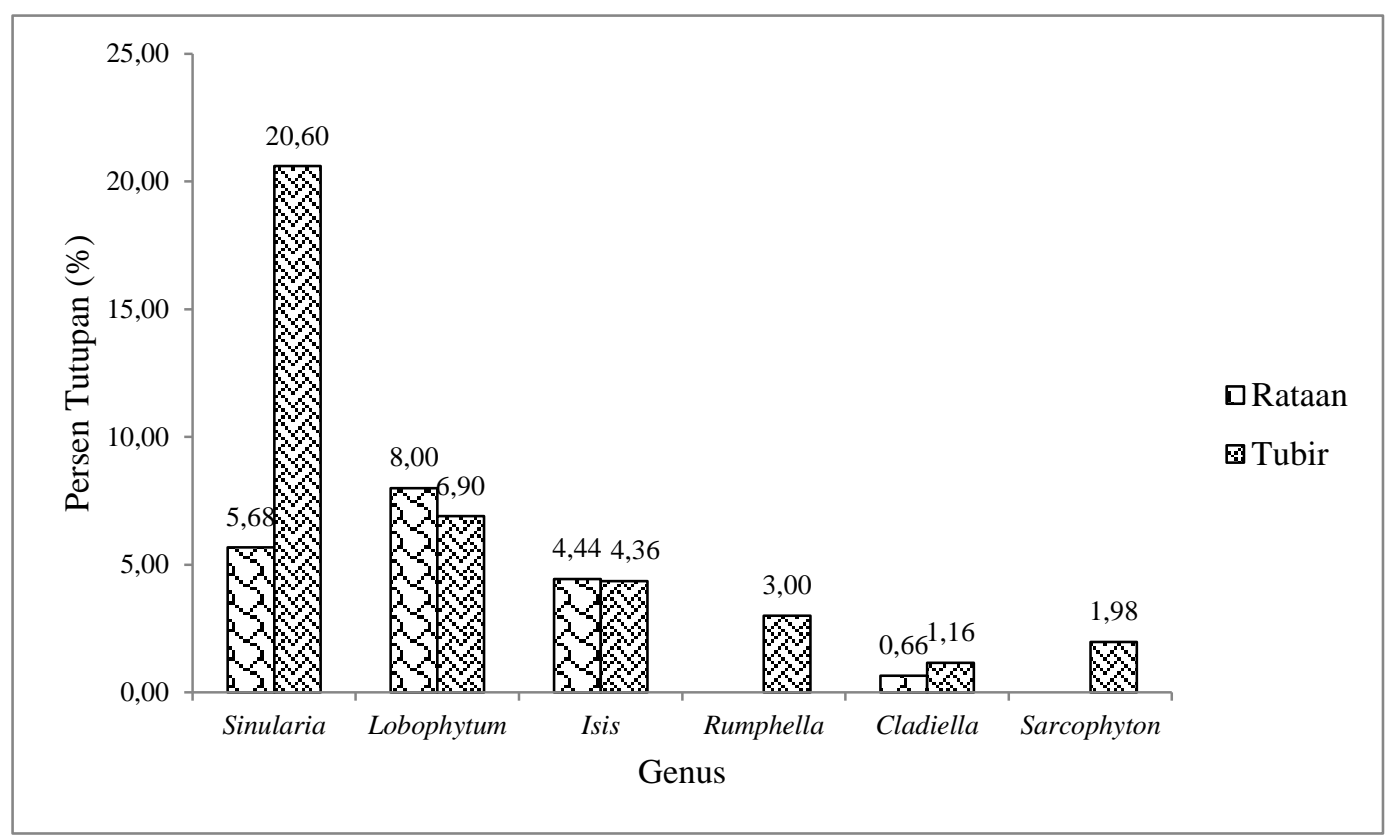

Gambar 4. Persentase Tutupan Karang Lunak di Stasiun II

Persentase tutupan tertinggi stasiun III di daerah tubir terdapat pada genus Sinularia dengan persentase $(1,82 \%)$ dan yang paling rendah ditemukan pada genus Rumphella yaitu $(0,92 \%)$. Sedangkan karang lunak di daerah rataan hanya terdapat 1 (satu) genus yaitu Sinularia dengan persentase tutupan $(0,92 \%)$.

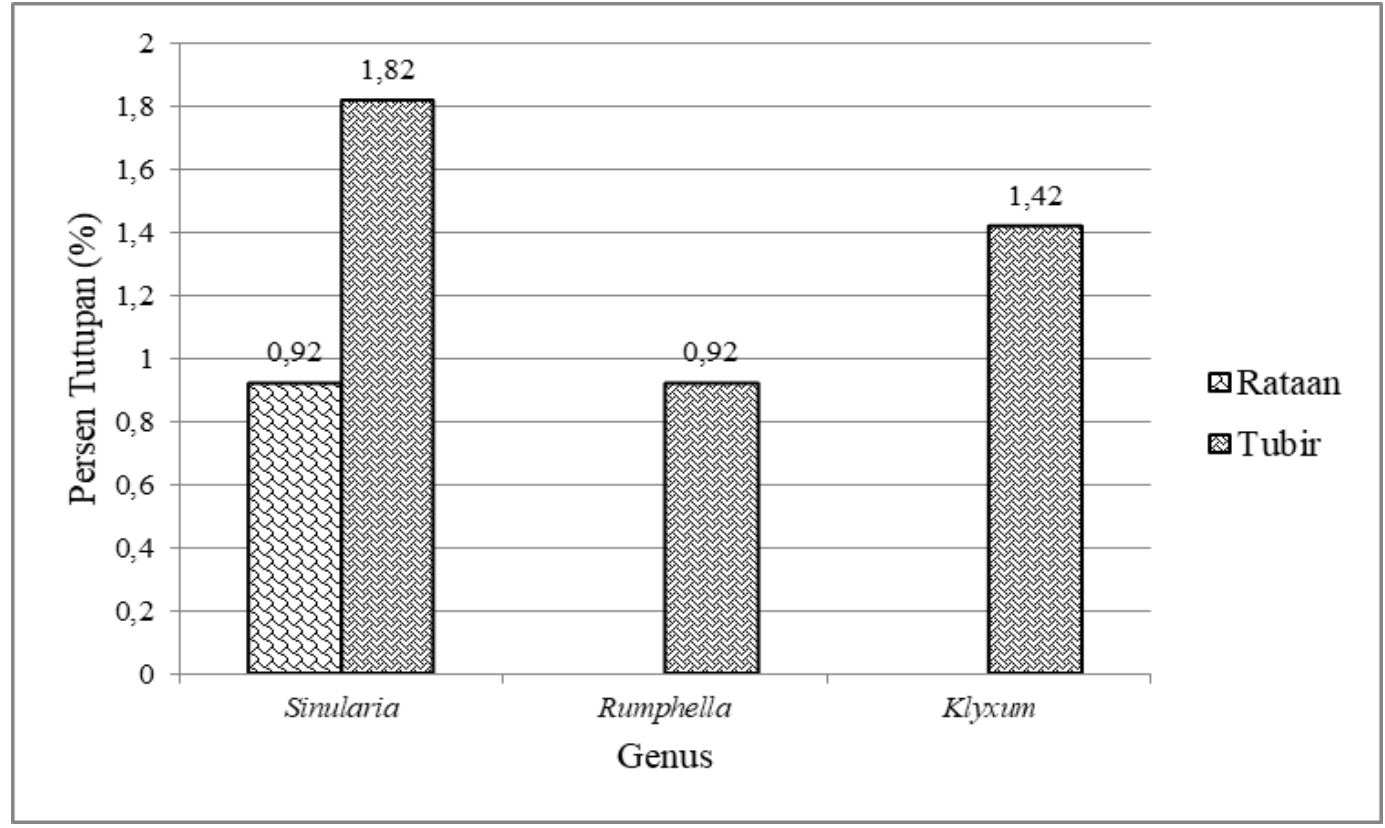

Gambar 5. Persentase Tutupan Karang Lunak di Stasiun III 
Hasil analisis tutupan karang lunak di stasiun IV menunjukan genus Sinularia memiliki persentase paling tinggi untuk daerah tubir yaitu $(9,36 \%)$ dan terendah pada genus Sarcophyton (1,56\%). Sedangkan di daerah rataan dengan persentase tutupan tertinggi berada pada genus Lobophytum yaitu $(4,1 \%)$ dan paling terendah pada genus Sarcophyton $(0,3 \%)$.

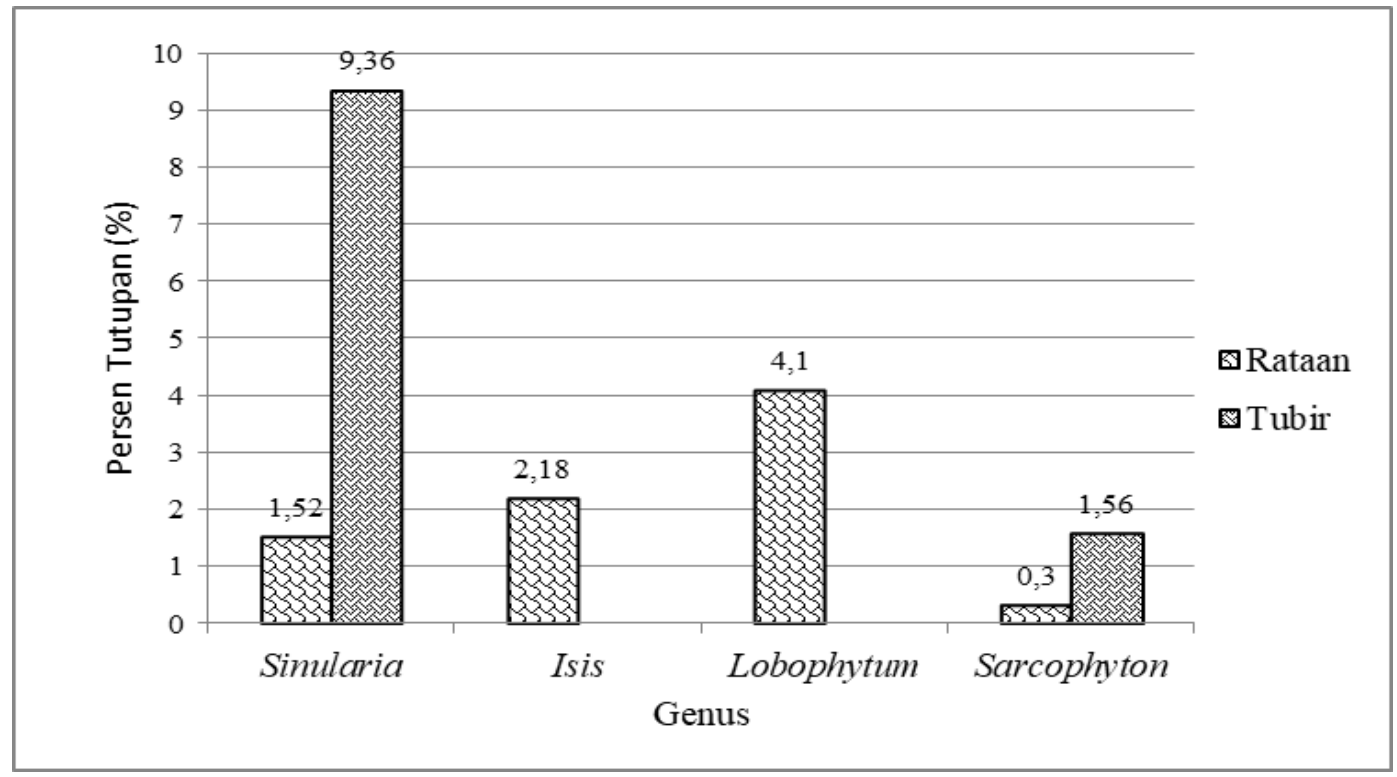

Gambar 6. Persentase Tutupan Karang Lunak di Stasiun IV

Hasil pengamatan karang lunak secara keseluruhan pada empat stasiun daerah rataan maupun daerah tubir telah ditemukan 7 genus karang lunak dengan persentase tutupan bervariasi (Gambar 7).

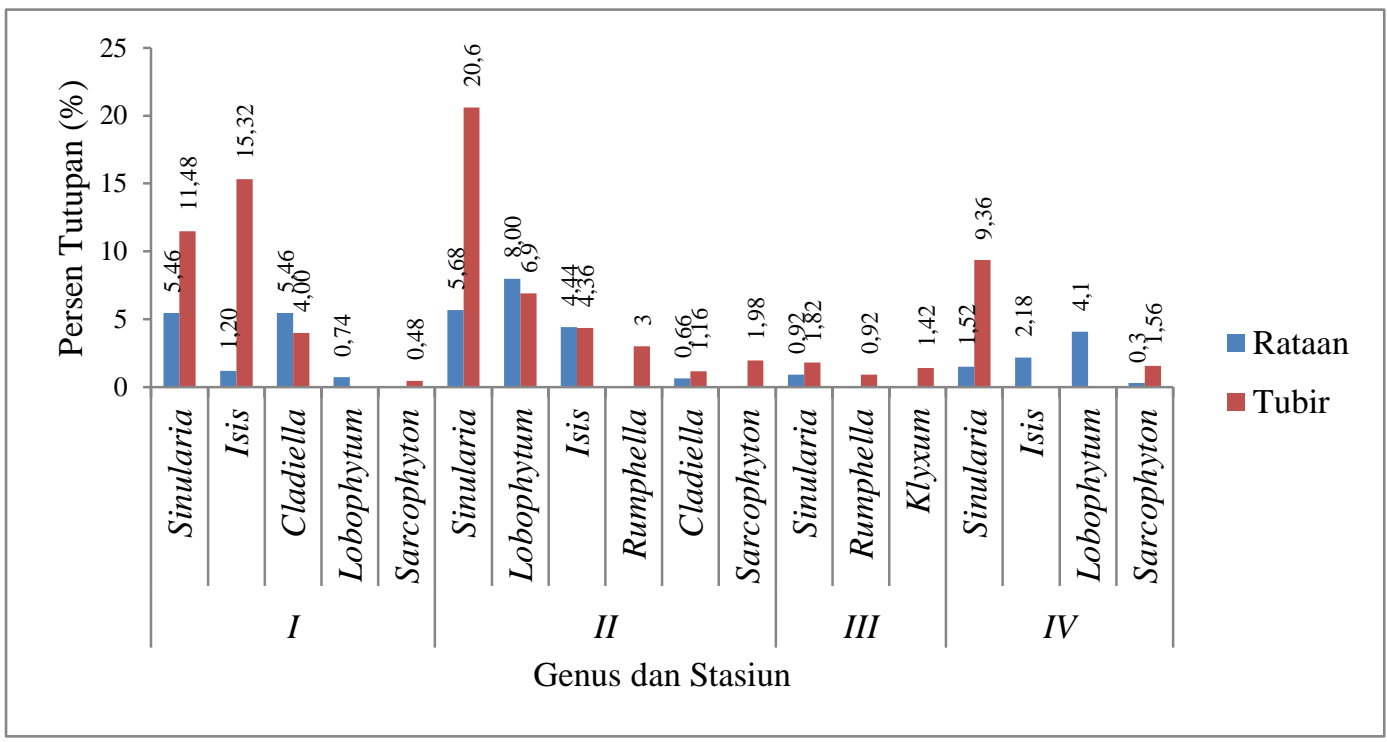

Gambar 7. Tutupan karang semua stasiun 
Adapun genus tertinggi di daerah rataan terdapat pada Lobophytum (8,0\%) dan terendah Sarcophyton (0,3\%). Menurut Manuputty (1996), Lobophytum merupakan karang lunak yang dapat ditemukan pada daerah rataan terumbu hingga kedalaman 7 (tujuh) meter. Bila diperhatikan pada pola zonasi pertumbuhan karang lunak yang digambarkan oleh (Manuputty, 1996) Lobophytum merupakan salah satu dari karang lunak yang memiliki daya adaptasi terhadap kondisi lingkungan, karena dapat hidup hingga pada perairan dangkal. Penelitian lain yang dilakukan oleh (Nababan et al., 2015), juga menemukan karang lunak Lobophytum merupakan kelompok karang yang mendominasi daerah rataan dengan persentase karang lunak tertinggi.

\section{KESIMPULAN}

Hasil penelitian yang dapat disimpulkan adalah perairan desa Pandanga pada daerah rataan ditemukan karang lunak dengan genus Sinularia, Isis, Cladiella, Lobophytum, dan Sarcophyton. Untuk daerah tubir ditemukan 7 (tujuh) genus Sinularia, Isis, Cladiella, Lobophytum, Sarcophyton, Klyxum, dan Rumphella. Sedangakan persen tutupan tertinggi untuk semua stasiun terdapat pada genus Sinularia $(20,6 \%)$ di daerah tubir sedangkan pada daerah rataan dengan persentase tertinggi terdapat pada genus Lobophytum $(8,0 \%)$.

\section{DAFTAR PUSTAKA}

English, S.; C. Wilkinson and V. Baker, 1997. Survey Manual For Tropical Marine Resources. Second Edition.Australia Institute of Marine Science. Townsville: $390 \mathrm{p}$.

Fabricius, K. and P. Alderslade. 2001. Soft Corals and Sea Fans A Comprehensive Guide to the Tropical Shallow Water Genera of the Central-West Pacific, the Indian Ocean and the Red Sea. Australian Institute of Marine Science. Townsville.

Gomez, E. D. and Yap H. 1984. Monitoring Reef Condition. Dalam Kenchington, R.A. and B. Hudson E.T. (ed). Coral Reef Management Hand Book. Unesco Regional Office for Science and Technology for South East Asia. Jakarta, 187-195 pp.

Haris A, Tuwo A, Annas A. 2010. Kelimpahan dan Distribusi Isis hippuris Di Perairan Spermonde Kota Makassar. Torani. Volume 20 (1): 816.

Kordi, H.G.M. 2010. Ekosistem Terumbu Karang; Potensi, Fungsi dan Pengelolaan. Penerbit. PT.Rineka Cipta. Jakarta. 
Lubis S.B, Suraij, Mudatstsir, Sari R.P, Miasto Y, Prabowo, Monintja M, Tery N, Annisa S, Sofiullah A, Nelly E, Subhan B. 2016. Pedoman Rehabilitasi Bambu Laut (Isis hippuris) Dengan Metode Transplantasi. Direktorat Konservasi dan Keanekaragaman Hayati Laut - KKP. Jakarta.

Manuputty A.E.W, 1996. Pengenalan Beberapa Karang Lunak (Octocorallia, Alcyonecea) di Lapangan. Oseana, Vol. XXI, No. 4:111. Puslitbang Oseanologi-LIPI, Jakarta.

Manuputty A.E.W, 2016. Karang Lunak (Octocorallia: Alcyonacea) di Perairan Biak Timur. Oseanologi dan Limnologi di Indonesia - LIPI. Volume 1 (2): 47-59.

Menteri Negara Lingkungan Hidup. 2001. Lampiran Surat Keputusan Mentri Negara Lingkungan Hidup No. 04 tahun 2001. tentang Kriteria Baku Mutu Kerusakan Terumbu Karang. Jakarta.

Nababan, P.M.S, Ruswahyuni, Suryanti. 2015. Penutupan Karang Lunak (Soft Coral) Pada Daerah Rataan dan Daerah Tubir di Pulau Cemara Kecil Kepulauan Karimun Jawa. Journal of Maquares. 4 (3): 164-169.

Nybakken, J.W. 1988. Biologi Laut: Suatu Pendekatan Ekologis. Penerbit. PT. Gramedia Pustaka Utama, Jakarta.

Suharsono. 2008. Jenis-Jenis Karang di Indonesia. Penerbit. LIPI Press, Anggota lkapi. Jakarta. 